\title{
Insulin Inhibits Neuropeptide Y Gene Expression in the Arcuate Nucleus through GABAergic Systems
}

\author{
Ikuko Sato, ${ }^{1}$ Hiroshi Arima, ${ }^{1}$ Noriyuki Ozaki, ${ }^{2}$ Minemori Watanabe, ${ }^{1}$ Motomitsu Goto, ${ }^{1}$ Masayuki Hayashi, ${ }^{1}$ \\ Ryouichi Banno, ${ }^{1}$ Hiroshi Nagasaki, ${ }^{1}$ and Yutaka Oiso ${ }^{1}$ \\ ${ }^{1}$ Department of Endocrinology and Diabetes, Field of Internal Medicine, and ${ }^{2}$ Department of Functional Anatomy and Neuroscience, Nagoya University \\ Graduate School of Medicine, Showa-ku, Nagoya 466-8550, Japan
}

Neuropeptide Y (NPY) in the arcuate nucleus is an orexigenic hormone of which levels are regulated by humoral as well as neural signals. In this study, we examined the regulation of NPY gene expression in the arcuate nucleus in hypothalamic organotypic cultures. Dexamethasone (DEX) $\left(10^{-9}\right.$ to $\left.10^{-7} \mathrm{M}\right)$ significantly increased NPY mRNA expression, and the effects were not influenced by coincubation with the sodium channel blocker tetrodotoxin (TTX), indicating that the action of DEX is independent of action potentials. Conversely, insulin $\left(10^{-11}\right.$ to $\left.10^{-9} \mathrm{M}\right)$ significantly inhibited NPY expression stimulated by DEX, and the inhibitory action of insulin was abolished in the presence of TTX. Because GABA and its receptors are expressed in the arcuate nucleus in vivo, we examined whether GABAergic systems were involved in the insulin action. The $\mathrm{GABA}_{\mathrm{B}}$ agonist baclofen significantly inhibited NPY expression stimulated by DEX, and the inhibitory action of insulin was completely abolished in the presence of either the $\mathrm{GABA}_{\mathrm{A}}$ antagonist bicuculline or the $\mathrm{GABA}_{\mathrm{B}}$ antagonist CGP35348 ( $p$-3-aminopropyl-p-diethoxymethyl phosphoric acid). Furthermore, increases in the GABA-synthesizing enzyme glutamic acid decarboxylase 65 (GAD65) mRNA expression preceded decreases in NPY mRNA expression in the arcuate nucleus in the cultures. Experiments in vivo also demonstrated that increases in GAD65 mRNA expression in the arcuate nucleus preceded decreases in the NPY mRNA expression in a fasting-refeeding paradigm and that intracerebroventricular injection of insulin increased GAD65 mRNA expression in the arcuate nucleus in fasted rats. These data suggest that insulin inhibits NPY gene expression in the arcuate nucleus through GABAergic systems.

Key words: neuropeptide Y; arcuate nucleus; glucocorticoid; insulin; GABA; GABA receptors

\section{Introduction}

The arcuate nucleus in the hypothalamus is supposed to be the integrative site that receives signals from the periphery reflecting energy status and projects to other hypothalamic nuclei, such as the paraventricular nucleus (PVN) (Kalra and Kalra, 2004). Neuropeptide Y (NPY) expressed in the arcuate nucleus is one of the most potent stimulants for food intake in the CNS such that central injection of NPY readily evokes robust feeding in satiated rats (Clark et al., 1984).

Among many signals in the periphery identified so far, insulin has been implicated as one of the key regulators that inhibit food intake (Schwartz et al., 1992a). The central action of insulin on energy balance is supported by findings that centrally injected insulin inhibited food intake (Woods et al., 1979) and that knock-out mice for insulin receptors in the CNS are hyperphagic and obese (Brüning et al., 2000). Several lines of evidence suggest that the action of insulin is mediated via NPY neurons in the

\footnotetext{
Received March 4, 2005; revised Aug. 12, 2005; accepted Aug. 15, 2005.

This work was supported in part by a grant-in-aid for Scientific Research from the Ministry of Health, Labor, and Welfare of Japan.

Correspondence should be addressed to Dr. H. Arima, Department of Endocrinology and Diabetes, Field of Internal Medicine, Nagoya University Graduate School of Medicine, 65 Tsurumai-cho, Showa-ku, Nagoya 466-8550, Japan.E-mail:arima105@med.nagoya-u.ac.jp.

DOI:10.1523/JNEUROSCI.2739-05.2005

Copyright $\odot 2005$ Society for Neuroscience $\quad$ 0270-6474/05/258657-08\$15.00/0
}

arcuate nucleus: (1) insulin receptors are expressed in the arcuate nucleus, and central injection of insulin decreases NPY gene expression (Marks et al., 1990; Sipols et al., 1995; Benoit et al., 2002); (2) decreases in insulin levels induced by streptozotocin injection or food deprivation lead to increases in the NPY gene expression (Schwartz et al., 1992b; Sipols et al., 1995); (3) decreases in insulin receptor expression in the arcuate nucleus by injection of the antisense induced increases in NPY gene expression (Obici et al., 2002); and (4) insulin deficiency induced by streptozotocin did not lead to hyperphagia in NPY knock-out mice (Sindelar et al., 2002). Although these data strongly suggest that insulin acts on the NPY neurons in the arcuate nucleus, the detailed mechanisms have remained unclear.

On the other hand, there is compelling evidence to indicate that glucocorticoids enhance feeding and weight gain (Dallman et al., 2004). The arcuate nucleus could also be the site for glucocorticoid action, because glucocorticoid receptor (GR) is expressed in the NPY neurons (Hisano et al., 1988), and peripheral as well as central injection of glucocorticoids increased the NPY expression (Wilding et al., 1993; Zakrzewska et al., 1999). More importantly, NPY gene expression was not increased by insulin deficiency if rats were adrenalectomized (Ponsalle et al., 1992; Strack et al., 1995). These data suggest that insulin and glucocorticoids interact with each other to regulate NPY gene expression, although the exact sites of the interaction are not clear. 
To determine how glucocorticoids and insulin regulate NPY gene expression and whether there is any interaction between the two hormones at the level of the arcuate nucleus, we examined the NPY gene expression in the arcuate nucleus in hypothalamic organotypic cultures, which have been shown to maintain the intrinsic properties (Arima et al., 2002; Kuwahara et al., 2003). Our data suggest the possible role of GABA, a predominant inhibitory neurotransmitter in the brain, in mediating the inhibitory action of insulin on NPY gene expression stimulated by glucocorticoids.

\section{Materials and Methods}

Slice-explant culture procedure. Hypothalamic slice-explant cultures were performed as described previously (Arima et al., 2002; Kuwahara et al., 2003). Sprague Dawley pups, 7-9 d old (Chubu Science Materials, Nagoya, Japan) (lights on from 9:00 A.M. to 9:00 P.M.), were killed by decapitation, and hypothalamic tissues were sectioned at $350 \mu \mathrm{m}$ thickness on a Mcllwain tissue chopper (Mickle Laboratory Engineering, Surrey, UK). Three coronal slices containing arcuate nucleus were separated and placed in HBSS (Invitrogen, Grand Island, NY) enriched with glucose. Selected sections were trimmed dorsally above the top of the third ventricle and laterally from the arcuate nucleus. Explants from individual rats were placed on $0.4 \mu \mathrm{m}$ Millicell-CM filter inserts (pore size, $0.4 \mu \mathrm{m}$; diameter, $30 \mathrm{~mm}$; Millipore, Billerica, MA), and each filter insert was placed in a Petri dish $(35 \mathrm{~mm})$ containing $1.1 \mathrm{ml}$ of culture medium. Cultures were performed at $36.5^{\circ} \mathrm{C}$ in $5 \% \mathrm{CO}_{2}$ enriched air under stationary conditions. The standard culture medium was composed of $50 \%$ Earle's MEM (Invitrogen), 25\% heat-inactivated horse serum (Invitrogen), HBSS (Invitrogen), $25 \mathrm{U} / \mathrm{ml}$ penicillin/streptomycin (Invitrogen), $1 \mathrm{~mm}$ L-glutamine (Invitrogen), and $33 \mathrm{~mm}$ glucose. The serum-free medium was composed of 75\% Earle's MEM, 25\% HBSS, $25 \mathrm{U} / \mathrm{ml}$ penicillin/streptomycin, $1 \mathrm{~mm}$ L-glutamine, and $5.5 \mathrm{~mm}$ glucose. Cultures were maintained in the standard medium for $15 \mathrm{~d}$ so that the slices became thin enough to perform in situ hybridization, and the medium was then changed to defined serum-free medium for an additional $3 \mathrm{~d}$ before subjecting slices to different experimental conditions. The standard medium was changed three times a week, and the serum-free medium was changed every $24 \mathrm{~h}$. All experiments were performed on day 18 , and the slices were fixed with $4 \%$ formaldehyde in PBS for $30 \mathrm{~min}$, washed twice in PBS, mounted onto poly-L-lysine-coated slides, dried, and kept at $-80^{\circ} \mathrm{C}$ until processed for in situ hybridization.

Effects of dexamethasone and insulin on NPY mRNA expression. To examine the time course effects of dexamethasone (DEX) (Sigma, St. Louis, MO) on NPY mRNA expression, slices were incubated with $10^{-7}$ M DEX for 4, 12, and $24 \mathrm{~h}$. Control slices were incubated with vehicle $(0.1 \%$ ethanol $)$ for $24 \mathrm{~h}$. To examine the dose-dependent effects of DEX on NPY mRNA expression, slices were incubated with $10^{-9}$ to $10^{-7} \mathrm{M}$ DEX or vehicle for $24 \mathrm{~h}$. To examine the effects of insulin on NPY mRNA expression in the arcuate nucleus of hypothalamic organotypic cultures, slices were incubated with $10^{-11}$ to $10^{-9} \mathrm{M}$ insulin (Humulin R; Eli Lilly Japan, Kobe, Japan) or vehicle ( $0.9 \%$ saline) for $24 \mathrm{~h}$. To examine the possible interaction between insulin and DEX on the regulation of NPY mRNA expression, slices were incubated with $10^{-11}$ to $10^{-9} \mathrm{M}$ insulin or vehicle in the presence of $10^{-8} \mathrm{M}$ DEX. To see the time course of insulin action, slices were incubated with $10^{-11} \mathrm{M}$ insulin for $0,6,12$, or $24 \mathrm{~h}$, whereas $10^{-8} \mathrm{M}$ DEX was added to medium for $24 \mathrm{~h}$ in all groups. The effects of DEX and insulin on NPY mRNA expression were also examined in the presence of the sodium channel blocker tetrodotoxin (TTX) (1 $\mu \mathrm{M}$; Sankyo, Tokyo, Japan).

Effects of GABA agonists and antagonists and glutamate antagonists on NPY mRNA expression. Slices were incubated with $10^{-6}$ to $10^{-4} \mathrm{M}$ $\mathrm{GABA}_{\mathrm{A}}$ agonist muscimol (Sigma), $10^{-6}$ to $10^{-4} \mathrm{M} \mathrm{GABA}_{\mathrm{B}}$ agonist baclofen (Sigma), NMDA glutamate receptor antagonist DL-2-amino-5phosphonopentanoic acid (AP-5) (100 $\mu \mathrm{M}$; Sigma), non-NMDA receptor antagonist 6-cyano-7-nitroquinoxaline-2,3-dione (CNQX) (20 $\mu \mathrm{M}$; (Sigma), or vehicle $\left(10^{-4} \mathrm{M} \mathrm{NaOH}\right.$ for baclofen, $5 \times 10^{-6} \mathrm{M} \mathrm{HCl}$ for muscimol, water for AP-5, and DMSO for CNQX) in the presence or absence of $10^{-8} \mathrm{M}$ DEX for $24 \mathrm{~h}$. Slices were also incubated with
GABA $_{\mathrm{A}}$ antagonist bicuculline $\left(10^{-4} \mathrm{M}\right.$; Sigma $)$ and $\mathrm{GABA}_{\mathrm{B}}$ antagonist CGP35348 ( $p$-3-aminopropyl-p-diethoxymethyl phosphoric acid) (1 $\mathrm{mM}$; Sigma) in the presence of $10^{-8} \mathrm{M}$ DEX for $24 \mathrm{~h}$. To assess whether or not the action of insulin was mediated via GABAergic systems, slices were incubated with $10^{-9} \mathrm{M}$ insulin and $10^{-8} \mathrm{M}$ DEX in the presence of either bicuculline or CGP35348 for $24 \mathrm{~h}$.

Expression of $m R N A$ for GABA receptors and glutamic acid decarboxylase in hypothalamic slices. To see the distribution of GABA receptors in the hypothalamic slices, the expressions of mRNA for $G_{A B A}$ and $\mathrm{GABA}_{\mathrm{B}}$ receptors were first examined in the slices with in situ hybridization using antisense and sense probes. To see whether GABA receptors and glutamic acid decarboxylase (GAD) 65 mRNA were expressed in the arcuate nucleus in the hypothalamic slices, the slices were cut into $20 \mu \mathrm{m}$ thickness on a cryostat after being fixed with formaldehyde. Whereas dual in situ hybridization was performed for GAD and NPY mRNA, the distribution of the transcripts for GABA receptors was compared with that for NPY in adjacent sections because the expression levels of mRNA for GABA receptors were relatively low in hypothalamic slices. To examine whether insulin treatment affected GAD65 mRNA expression, hypothalamic slices were incubated with $10^{-9} \mathrm{M}$ insulin for 0,6 , or $24 \mathrm{~h}$, whereas $10^{-8} \mathrm{M}$ DEX was added to medium for $24 \mathrm{~h}$ in all groups. To see the changes in GAD65 mRNA expression levels in the NPY neurons, sections were cut into $20 \mu \mathrm{m}$ thickness as described above, and in situ hybridization for GAD65 and NPY mRNA was performed in adjacent sections.

Fasting-refeeding experiments. Male Sprague Dawley rats (body weight, 250-300 g; Chubu Science Materials) were housed individually in plastic cages under controlled conditions $\left(23.0 \pm 0.5^{\circ} \mathrm{C}\right.$; lights on from 9:00 A.M. to 9:00 P.M.). All rats except for control group, which had access to food ad libitum until the experiments, were deprived of food for $48 \mathrm{~h}$. Normal rat chow was given to the rats at 9:00 A.M., and food consumption was monitored. Rats were decapitated before and 2, 4, 6, 12, and $24 \mathrm{~h}$ after ad libitum refeeding. Rats were also decapitated without refeeding at 11:00 A.M. and 3:00 P.M. to see whether there were any differences in GAD mRNA expression levels at different times. The brains were immediately removed, frozen on dry ice, and stored at $-80^{\circ} \mathrm{C}$ until sectioning for in situ hybridization. Blood glucose levels were immediately measured after decapitation with a blood glucose monitor (TERUMO, Tokyo, Japan). Blood samples were collected into chilled tubes and separated by centrifugation $\left(3500 \mathrm{rpm}, 4^{\circ} \mathrm{C}, 15 \mathrm{~min}\right.$ ), and serum was stored at $-80^{\circ} \mathrm{C}$ until the insulin determination. Serum insulin levels were measured with an ELISA commercial kit (Shibayagi, Gunma, Japan) using rat insulin as a standard.

Effects of intracerebroventricular injection of insulin on GAD mRNA expression. Seven days before experiments, rats were anesthetized with an intraperitoneal injection of pentobarbital $(50 \mathrm{mg} / \mathrm{kg})$ for implantation of a 21 gauge stainless steel cannula stereotaxically into the lateral ventricle. The coordinates of intracerebroventricular operation were $0.8 \mathrm{~mm}$ posterior to the bregma, $1.4 \mathrm{~mm}$ lateral to the midline, and $4.0 \mathrm{~mm}$ below the surface of the skull. After $48 \mathrm{~h}$ food deprivation, either $30 \mathrm{mIU}$ of insulin (Humulin $\mathrm{R}$ ) or vehicle ( $0.15 \mathrm{M}$ saline) was injected through an intracerebroventricular cannula at a volume of $10 \mu \mathrm{l}$ in $30 \mathrm{~s}$ between 9:00 A.M. and 9:30 A.M. The rats were decapitated $2 \mathrm{~h}$ after injection, and the brains were immediately removed, frozen on dry ice, and stored at $-80^{\circ} \mathrm{C}$ until sectioning for in situ hybridization. All procedures were performed in accordance with institutional guidelines for animal care at Nagoya University Graduate School of Medicine.

In situ hybridization and quantification. Six sets of sequential coronal sections $(12 \mu \mathrm{m})$ of brains from in vivo experiments were cut on a cryostat at $2.8 \mathrm{~mm}$ caudal from bregma according to the brain atlas of Paxinos and Watson (1998), thaw mounted onto poly-L-lysine-coated slides, and stored at $-80^{\circ} \mathrm{C}$ until hybridization. The RNA probes were generated from the plasmids of NPY (kindly provided by Dr. S. L. Sabol, Laboratory of Biochemical Genetics, National Heart, Lung, and Blood Institute, National Institutes of Health, Bethesda, MD), GAD65 (kindly provided by Dr. N. Tillakaratne, Department of Physiological Science, University of California, Los Angeles, Los Angeles, CA), GABA $\mathrm{A} \beta 3$ (kindly provided by Dr. K. Kobayashi, Department of Molecular Genetics, Fukushima Medical University School of Medicine, Fukushima, Japan), and GABA 
R2 (kindly provided by K. Kaupmann, Novartis Institute for Biomedical Research, Novartis Pharma AG, Basel, Switzerland) containing 511 bp, $2.3 \mathrm{~kb}, 960 \mathrm{bp}$, and $720 \mathrm{bp}$ cDNA, respectively. High specific probes were synthesized using $55 \mu \mathrm{Ci}\left[{ }^{35} \mathrm{~S}\right] \mathrm{UTP}$ and $171 \mu \mathrm{Ci}\left[{ }^{35} \mathrm{~S}\right] \mathrm{CTP}$ (PerkinElmer Life Science, Natick, MA), Riboprobe Combination System (Promega, Madison, WI), $15 \mathrm{U}$ of RNasin, $1 \mu \mathrm{g}$ of linearized template, and $15 \mathrm{U}$ of T3 or T7 RNA polymerase. After 60 min incubation at $42^{\circ} \mathrm{C}$, the cDNA template was digested with DNAase for $10 \mathrm{~min}$ at $37^{\circ} \mathrm{C}$. Radiolabeled RNA products were purified using quick-spin columns (Roche Diagnostics, Indianapolis, IN), precipitated with ethanol, and resuspended in 100 $\mu \mathrm{l}$ of $10 \mathrm{~mm}$ Tris-HCl, pH 7.5, containing 20 mм DTT. Digoxigeninlabeled antisense RNA probes from NPY cDNA templates were prepared by using digoxigenin-UTP (Roche Diagnostics).

Prehybridization, hybridization, and posthybridization procedures were performed as described previously (Kuwahara et al., 2003). In brief, after thawing at room temperature, sections were fixed in $4 \%$ formaldehyde in PBS for $5 \mathrm{~min}$ and acetylated with $0.25 \%$ acetic anhydride in 0.1 $\mathrm{M}$ triethanolamine and $0.9 \% \mathrm{NaCl}, \mathrm{pH} 8$, for $10 \mathrm{~min}$ at room temperature. Sections were then dehydrated in $70,80,95$, and $100 \%$ ethanol, delipidated in chloroform, and hybridized overnight at $55^{\circ} \mathrm{C}$ with $2 \times$ $10^{6} \mathrm{cpm}$ of ${ }^{35} \mathrm{~S}$-labeled probes in $90 \mu \mathrm{l}$ of hybridization buffer $(50 \%$ formamide, $200 \mathrm{~mm} \mathrm{NaCl}, 2.5 \mathrm{~mm}$ EDTA, 10\% dextran sulfate, 250 $\mu \mathrm{g} / \mathrm{ml}$ yeast tRNA, $50 \mathrm{~mm}$ dithiothreitol, and $1 \times$ Denhardt's solution). At the end of incubation, sections were subjected to consecutive washes in $4 \times$ SSC for $15 \mathrm{~min}$ at room temperature and $50 \%$ formamide $/ 250 \mathrm{~mm}$ $\mathrm{NaCl}$ containing dithiothreitol for $15 \mathrm{~min}$ at $60^{\circ} \mathrm{C}$. After treatment with RNAase A $(20 \mu \mathrm{g} / \mathrm{ml})$ for $30 \mathrm{~min}$ at $37^{\circ} \mathrm{C}$, sections were washed with $2 \times$ SSC, $1 \times$ SSC, and $0.5 \times$ SSC for $5 \mathrm{~min}$ at room temperature, followed by washes with $0.1 \times \mathrm{SSC}$ containing dithiothreitol for $15 \mathrm{~min}$ at $50^{\circ} \mathrm{C}, 0.1 \times$ SSC to cool at room temperature, and $70 \%$ ethanol for $15 \mathrm{~s}$. To visualize digoxigenin staining, sections were rinsed twice in buffer $1(100 \mathrm{~mm}$ Tris- $\mathrm{HCl}$ and $150 \mathrm{~mm} \mathrm{NaCl}, \mathrm{pH}$ 7.5) for $5 \mathrm{~min}$, followed by $30 \mathrm{~min}$ in buffer 1 containing $3 \%$ normal goat serum and $0.3 \%$ Triton X-100, before overnight incubation with alkaline phosphatase-conjugated antidigoxigenin antiserum (Roche Diagnostics; 1:2000 in 3\% normal goat serum $/ 0.3 \%$ Triton X-100 in buffer 1$)$. Sections were consecutively rinsed in buffer 1 for $10 \mathrm{~min}$, in buffer 2 ( $100 \mathrm{~mm}$ Tris- $\mathrm{HCl}, 100 \mathrm{~mm} \mathrm{NaCl}$, and $50 \mathrm{mM} \mathrm{MgCl}_{2}, \mathrm{pH} 9.5$ ) for $5 \mathrm{~min}$, and incubated for $30 \mathrm{~min}$ at $37^{\circ} \mathrm{C}$ in the dark in buffer 2 containing $0.34 \mathrm{mg} / \mathrm{ml}$ nitroblue toluidinium salt (Roche Diagnostics). Sections were rinsed four times in buffer 2, dipped briefly in distilled water and 70\% ethanol, and air dried.

Sections were exposed to Kodak BioMax MR films (Eastman Kodak, Rochester, NY) for various periods yielding appropriate signal intensities. The optimal densities (ODs) of the autoradiographs were quantified using a computer image analysis system (Imaging Research, St. Catharines, Ontario, Canada) and the public domain NIH Image program. Changes in NPY levels were quantified by measurements of the integrated $\mathrm{OD}(\mathrm{OD} \times$ area $)$ of the film images. As for the hypothalamic cultures, the total sum of OD signals of NPY mRNA in the bilateral arcuate nuclei in the three hypothalamic explants from each rat was used for the analysis. In each culture, control explants were involved, and the expression levels were expressed as 100. To measure GAD65 mRNA expression in the arcuate NPY neurons, the areas expressing NPY mRNA in adjacent sections were first delineated. The contour was then overlaid on the film of GAD65 mRNA expression, and the OD levels of GAD65 mRNA were measured for the analysis. The statistical analyses were performed with ANOVA, followed by Fisher's protected least significant difference test. Results are expressed as means \pm SE ( $n=10$ for organotypic cultures and $n=7$ for in vivo experiments), and differences were considered statistically significant at $p<0.05$.

Adjacent sections hybridized with antisense probes for $\mathrm{GABA}_{\mathrm{A}}$ receptor, $\mathrm{GABA}_{\mathrm{B}}$ receptor, or NPY mRNA were dipped in nuclear Kodak NTB2 emulsion (Eastman Kodak) and exposed for $24 \mathrm{~h}$ (NPY) or 3 weeks $\left(\mathrm{GABA}_{\mathrm{A}}\right.$ and $\mathrm{GABA}_{\mathrm{B}}$ receptors). To assist cellular localization of the hybridized signals, emulsion-dipped sections were stained with cresyl violet. The sections hybridized with digoxigenin-labeled NPY and ${ }^{35} \mathrm{~S}$ labeled GAD riboprobes were dipped in Ilford K.5D nuclear emulsion (Polysciences, Warrenton, PA) and developed after 1 week exposure. The number of cells stained with digoxigenin NPY were counted from five slices, and cells were considered to express GAD65 mRNA when the grains of GAD65 mRNA were more than threefold the background density.

\section{Results}

\section{Effects of DEX and insulin on NPY mRNA expression}

NPY mRNA is expressed in the arcuate nucleus in the hypothalamic organotypic cultures (Fig. 1). Incubation with DEX $\left(10^{-7}\right.$ M) significantly increased NPY expression at $4 \mathrm{~h}$, and the expression levels continued to increase until $24 \mathrm{~h}$ (Fig. 1a). The NPY mRNA expression was increased at $24 \mathrm{~h}$ by incubation with DEX in a dose-dependent manner (from $10^{-9}$ to $10^{-7} \mathrm{M}$ ) (Fig. 1b). Whereas NPY mRNA expression levels in the arcuate nucleus were not affected significantly in the absence of DEX by the incubation with any dose of insulin examined $\left(10^{-11}\right.$ to $\left.10^{-9} \mathrm{M}\right)$ for $24 \mathrm{~h}$ (Fig. 1c), NPY expression stimulated by DEX $\left(10^{-8} \mathrm{M}\right)$ was attenuated by incubation with insulin for $24 \mathrm{~h}$ significantly and dose dependently (Fig. 1d). The inhibitory effects of insulin $\left(10^{-9} \mathrm{M}\right)$ on NPY mRNA expression in the presence of DEX reached statistical significance at $12 \mathrm{~h}$ (Fig. 1e). The incubation with DEX $\left(10^{-8} \mathrm{M}\right)$ significantly increased the NPY mRNA expression even in the presence of TTX (Fig. 1f), indicating that action of DEX was independent of action potentials. Conversely, the inhibitory effects of insulin on NPY mRNA expression stimulated by DEX were completely abolished in the presence of TTX (Fig. 1f), indicating that insulin decreased NPY mRNA expression indirectly through neural transmission. Representative photographs are shown in Figure $1 g$. The concentrations of $10^{-8}$ and $10^{-9} \mathrm{M}$ for DEX and insulin, respectively, were used in the following experiments.

\section{Effects of GABA agonists and antagonists and glutamate antagonists on NPY mRNA expression}

The above data suggest that insulin decreased NPY mRNA expression by increasing the inhibitory neurotransmitters or decreasing the excitatory neurotransmitters. Because GABA and glutamate are the major inhibitory and excitatory transmitters in the brain, respectively, and exist in the arcuate nucleus (Decavel and van den Pol, 1992), we examined whether the stimulation of GABA receptors or blockade of glutamate receptors could mimic the insulin action. Incubation with a $\mathrm{GABA}_{\mathrm{A}}$ agonist muscimol $\left(10^{-6}\right.$ to $\left.10^{-4} \mathrm{M}\right)$ for $24 \mathrm{~h}$ did not significantly affect NPY mRNA expression in the arcuate nucleus in either the presence (Fig. 2c) or absence (data not shown) of DEX. However, similar to insulin action, incubation with the $\mathrm{GABA}_{\mathrm{B}}$ agonist baclofen $\left(10^{-6}\right.$ to $10^{-4} \mathrm{M}$ ) significantly decreased NPY expression stimulated by DEX (Fig. 2b), although it did not affect NPY expression in the absence of DEX (Fig. 2a). Incubation with antagonists of NMDA glutamate receptors (AP-5) or non-NMDA glutamate receptors (CNQX) did not affect NPY mRNA expression in the arcuate nucleus significantly in the absence (data not shown) or presence (Fig. 2d) of DEX. To further examine the possible role of GABAergic systems in the regulation of NPY gene expression in the arcuate nucleus, effects of GABA antagonists on NPY mRNA expression were examined. Incubation with the $\mathrm{GABA}_{\mathrm{A}}$ antagonist bicuculline $\left(10^{-4} \mathrm{M}\right)$ robustly increased NPY mRNA expression in the presence of DEX in the arcuate nucleus (Fig. 2e), suggesting that NPY mRNA expression is tonically inhibited by $\mathrm{GABA}_{\mathrm{A}}$ receptor-mediated signaling. Conversely, incubation with the $\mathrm{GABA}_{\mathrm{B}}$ antagonist CGP35348 $\left(5 \times 10^{-4} \mathrm{M}\right)$ did not affect NPY mRNA expression significantly in the presence of DEX (Fig. 2f). Insulin did not significantly decrease NPY expression stimulated by DEX in the presence of either bicuculline (Fig. 2e) or CGP35348 (Fig. 2f). 

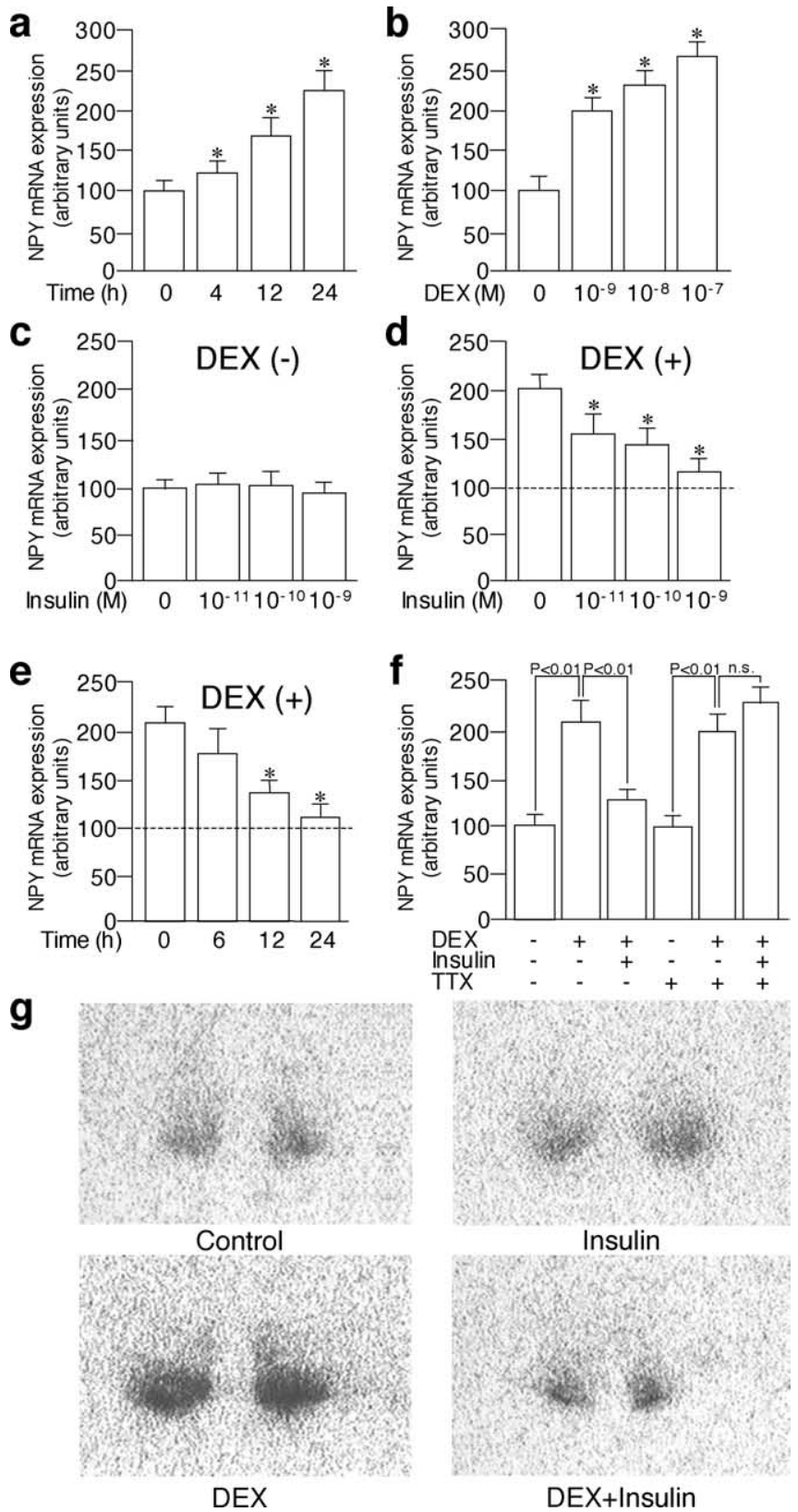

Figure 1. Effects of DEX and insulin on NPY mRNA expression in the arcuate nucleus in the organotypic cultures. $\boldsymbol{a}$, NPY expression was significantly increased with DEX $\left(10^{-7} \mathrm{M}\right)$ at $4 \mathrm{~h}$ and continued to increase until $24 \mathrm{~h} . \boldsymbol{b}$, Incubation with DEX $\left(10^{-9}\right.$ to $\left.10^{-7} \mathrm{M}\right)$ for $24 \mathrm{~h}$ increased NPY mRNA expression dose dependently. c, Incubation with insulin $\left(10^{-11}\right.$ to $\left.10^{-9} \mathrm{M}\right)$ for $24 \mathrm{~h}$ did not affect NPY mRNA expression significantly in the absence of DEX. $\boldsymbol{d}$, Incubation with insulin $\left(10^{-11}\right.$ to $\left.10^{-9} \mathrm{M}\right)$ for $24 \mathrm{~h}$ inhibited NPY mRNA expression stimulated by DEX $\left(10^{-8} \mathrm{M}\right)$ dose dependently. $\boldsymbol{e}$, Incubation with insulin $\left(10^{-9} \mathrm{M}\right)$ significantly inhibited NPY mRNA expression stimulated by DEX $\left(10^{-8} \mathrm{M}\right)$ at 12 and $24 \mathrm{~h}$. $f$, Whereas incubation with DEX $\left(10^{-8} \mathrm{M}\right)$ for $24 \mathrm{~h}$ increased NPY mRNA expression significantly even in the presence of $10^{-6} \mathrm{M}$ TTX, incubation with insulin $\left(10^{-9} \mathrm{M}\right)$ for $24 \mathrm{~h}$ did not inhibit NPY mRNA expression stimulated by DEX $\left(10^{-8} \mathrm{M}\right)$ in the presence of TTX.g, Representative autoradiographs showing NPY mRNA expression in the arcuate nucleus in the organotypic cultures are shown. The mean NPY expression levels in the absence of DEX (control) are expressed as 100 and are shown as dashed lines ( $\boldsymbol{d}$, $\boldsymbol{e})$. The results are expressed as means $\pm \mathrm{SE}(n=10) .{ }^{*} p<0.05$ versus control $(\boldsymbol{a}, \boldsymbol{b})$ or values stimulated by DEX $(\boldsymbol{d}, \boldsymbol{e})$. n.s., Not significant.

\section{Expression of GABA receptors and GAD mRNA}

The in situ hybridization with antisense probes demonstrated that the mRNA for $\mathrm{GABA}_{\mathrm{A}}$ and $\mathrm{GABA}_{\mathrm{B}}$ receptors were expressed throughout the hypothalamic slices, whereas no visible signals
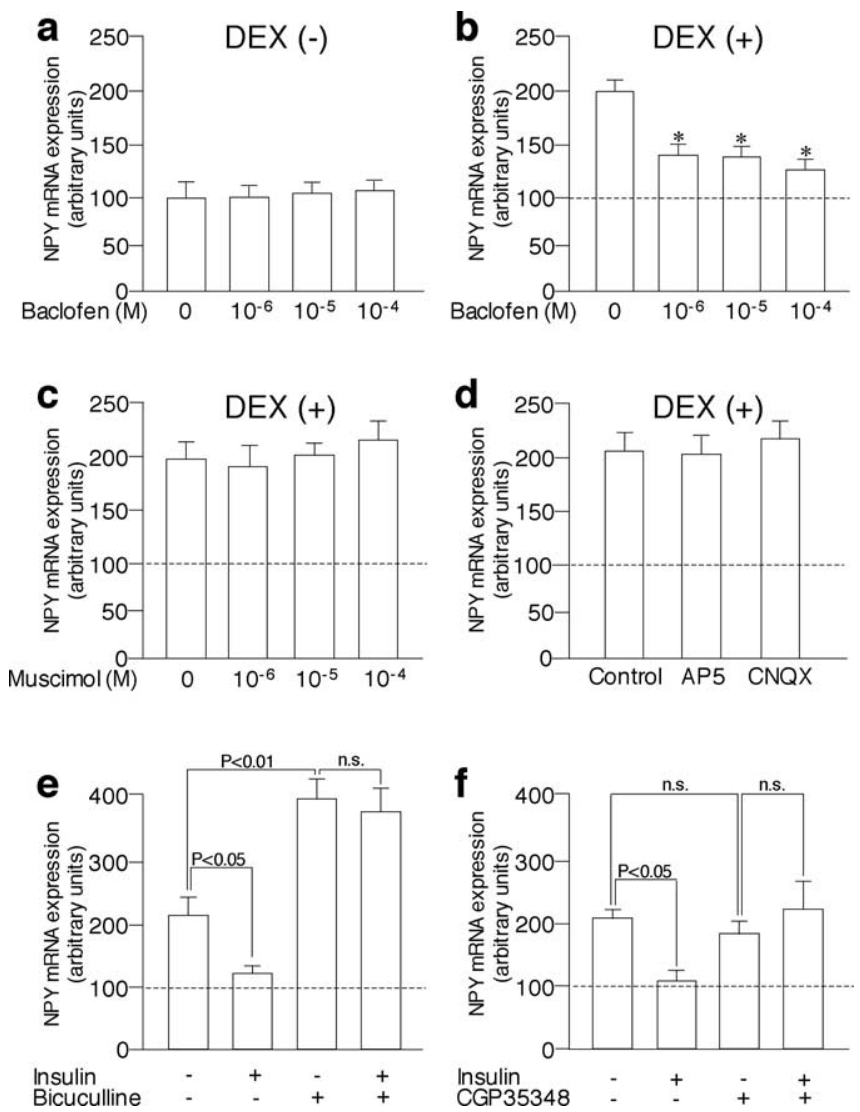

Figure 2. Effects of GABA agonists and antagonists and glutamate antagonists on NPY $m R N A$ expression in the arcuate nucleus in the organotypic cultures. $\boldsymbol{a}$, Incubation with $G_{A B A}$ agonist baclofen $\left(10^{-6}\right.$ to $\left.10^{-4} \mathrm{M}\right)$ did not affect NPY mRNA expression in the absence of DEX. $\boldsymbol{b}$, Incubation with baclofen $\left(10^{-6}\right.$ to $\left.10^{-4} \mathrm{M}\right)$ significantly inhibited NPY mRNA expression stimulated by DEX $\left(10^{-8} \mathrm{M}\right)$. c, Incubation with $\mathrm{GABA}_{\mathrm{A}}$ agonist muscimol $\left(10^{-6}\right.$ to $\left.10^{-4} \mathrm{M}\right)$ for $24 \mathrm{~h}$ did not significantly affect NPY mRNA expression stimulated by DEX $\left(10^{-8} \mathrm{M}\right) . \boldsymbol{d}$, Incubation with NMDA glutamate receptor antagonist AP-5 (100 $\mu \mathrm{M})$ or non-NMDA glutamate receptor antagonist CNQX $(20 \mu \mathrm{M})$ did not significantly affect NPY mRNA expression stimulated by DEX. $\boldsymbol{e}, \mathrm{GABA}_{\mathrm{A}}$ antagonist bicuculline $\left(10^{-4} \mathrm{M}\right)$ significantly increased NPY mRNA expression stimulated by DEX, and insulin did not inhibit NPY expression significantly in the presence of bicuculline. $\boldsymbol{f}$, Whereas incubation with $\mathrm{GABA}_{\mathrm{B}}$ antagonist CGP35348 (1 mm) by itself did not affect NPY mRNA expression significantly, the inhibitory action of insulin on NPY expression was abolished in the presence of CGP35348. The mean NPY expression levels in the absence of DEX are expressed as 100 and are shown as dashed lines. The results are expressed as means \pm SE $(n=10) .{ }^{*} p<0.05$ versus values stimulated by DEX. n.s., Not significant.

were detected with sense probes (Fig. $3 a-d$ ). Analyses of the emulsion-dipped slides showed that the distribution of $\mathrm{GABA}_{\mathrm{A}}$ and $\mathrm{GABA}_{\mathrm{B}}$ receptors overlapped that of NPY mRNA expression in the arcuate nucleus (Fig. $3 e-h$ ), suggesting that GABA receptors are expressed in the NPY neurons in the hypothalamic cultures as in vivo (Blasquez et al., 1994; Bäckberg et al., 2003). The dual in situ hybridization demonstrated that $\sim 87 \%$ (521 of 597 counted) of cells labeled with digoxigenin NPY in the arcuate nucleus expressed GAD65 mRNA in the organotypic cultures (Fig. 4a). The GAD65 mRNA levels in the arcuate NPY neurons were significantly increased by insulin treatment as early as $6 \mathrm{~h}$ and remained elevated for $24 \mathrm{~h}$ in the organotypic cultures (Fig. $4 b$ ). Representative photographs demonstrating changes in NPY and GAD65 mRNA are shown in Figure $4 c$.

\section{Fasting-refeeding experiments}

The changes in NPY and GAD65 mRNA expression in the arcuate nucleus, serum insulin levels, blood glucose levels, and cumula- 

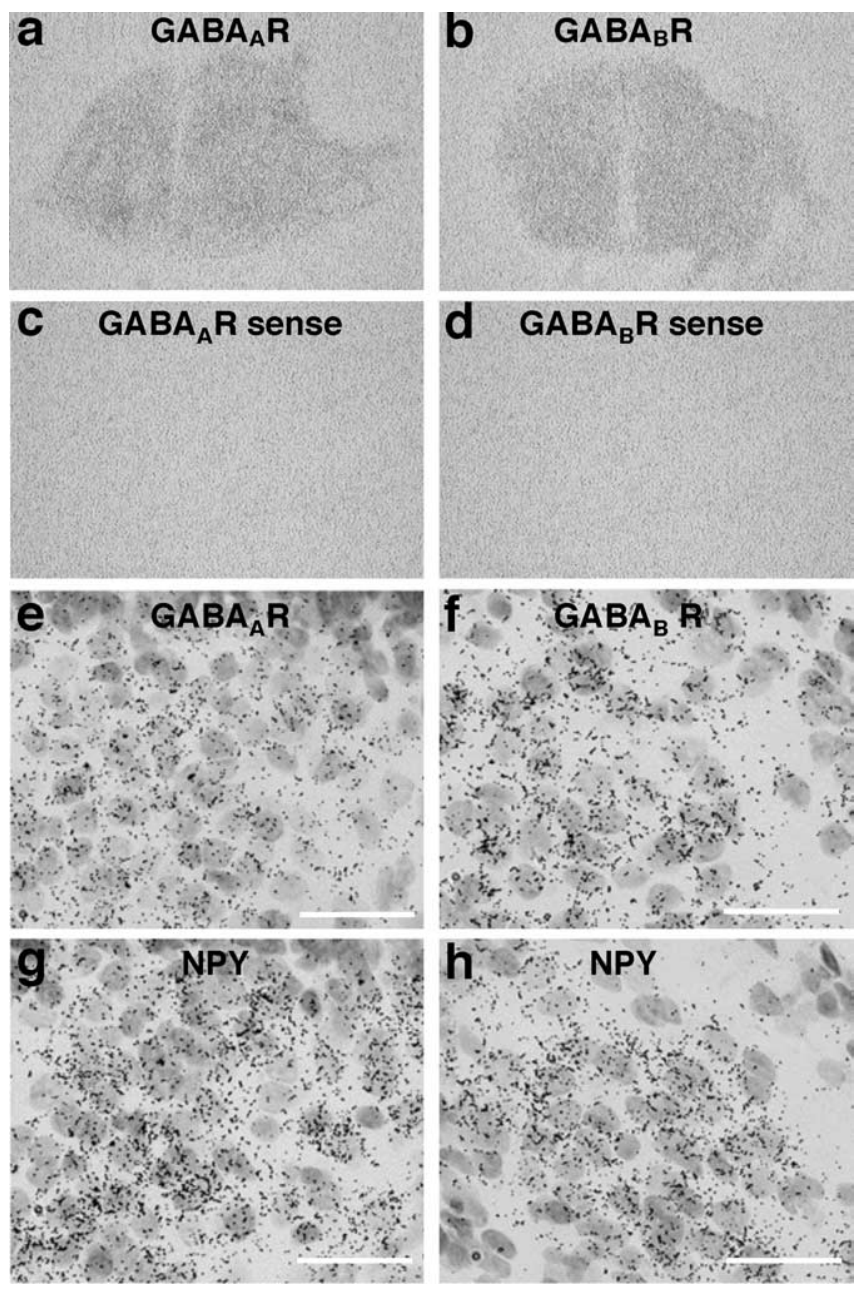

Figure 3. Expression of $m R N A$ for receptors of $G A B A_{A}\left(G A B A_{A} R\right)$ and $G A B A_{B}\left(G A B A_{B} R\right)$ in the hypothalamic organotypic cultures. The $m R N A$ for $G A B A_{A}$ and $G A B A_{B}$ receptors were expressed throughout the hypothalamic slices $(\boldsymbol{a}, \boldsymbol{b})$, whereas no visible signals were detected with sense probes $(\boldsymbol{c}, \boldsymbol{d})$. Expressions for $\mathrm{GABA}_{A}(\boldsymbol{e})$ and $\mathrm{GABA}_{B}(\boldsymbol{f})$ receptor mRNAs were compared with NPY mRNA expression $(\boldsymbol{g}, \boldsymbol{h})$ in the arcuate nucleus in adjacent slices. Scale bars, $50 \mu \mathrm{m}$.

tive food intake in a fasting-refeeding paradigm are shown in Figure 5. The serum insulin levels were significantly decreased by food deprivation for $48 \mathrm{~h}(24.8 \pm 10.1 \mathrm{pM}$ vs control rats with ad libitum feeding, $608.1 \pm 72.5 \mathrm{pm} ; p<0.01)$ but started to increase after refeeding and remained elevated for $24 \mathrm{~h}$ (Fig. $5 c$ ). The blood glucose levels were also significantly decreased by food deprivation for $48 \mathrm{~h}(5.2 \pm 0.3 \mathrm{~mm}$ vs control rats with ad libitum feeding, $6.9 \pm 0.2 \mathrm{~mm} ; p<0.01)$ but increased after refeeding and remained elevated for $24 \mathrm{~h}$ (Fig. $5 d$ ). The NPY mRNA expression in the arcuate nucleus was significantly increased after food deprivation (580.8 \pm 68.7 vs control rats with ad libitum feeding, $100.0 \pm 32.4$ arbitrary units; $p<0.01$ ) (Fig. $5 a$ ). After refeeding, the expression levels of NPY mRNA were gradually decreased, and the differences reached statistical significance at $24 \mathrm{~h}$ compared with the values before refeeding (Fig. $5 a$ ). Expression levels of GAD65 mRNA were not affected by food deprivation but significantly increased $2 \mathrm{~h}$ after refeeding and remained elevated for $24 \mathrm{~h}$ (Fig. 5b). There were no significant differences in GAD65 mRNA levels between rats decapitated at 9:00 A.M., 11:00 A.M., and 3:00 P.M. without refeeding (data not shown). Representative photographs showing changes in NPY and GAD65 mRNA expression in the arcuate nucleus in vivo are shown in Figure $5 f$. a

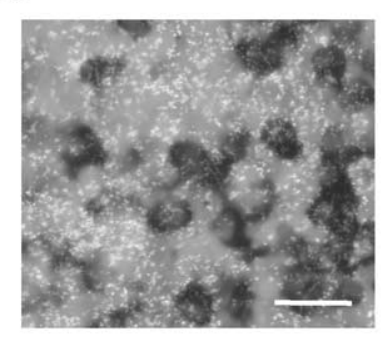

b

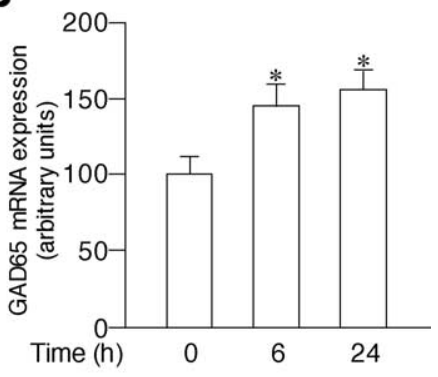

C

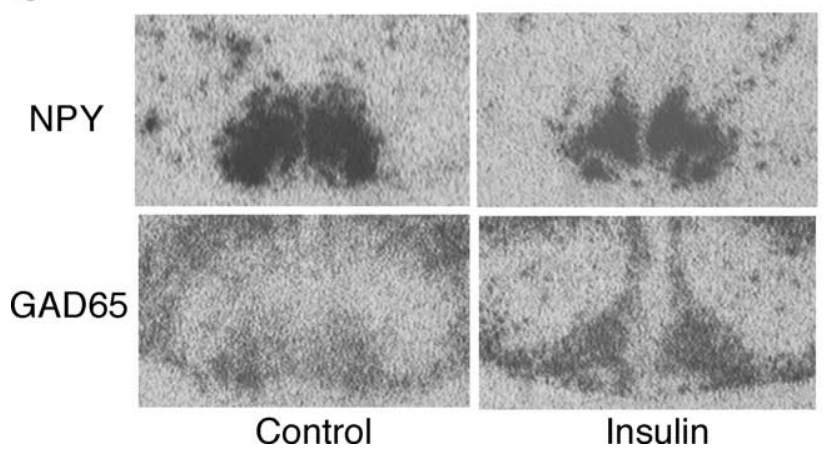

Figure 4. Effects of insulin on GAD65 mRNA expression in the arcuate nucleus in the organotypic cultures. $\boldsymbol{a}, \mathrm{GAD}$ mRNA (shown by silver grains) is expressed in digoxigenin-stained NPY neurons. $\boldsymbol{b}$, Insulin treatment significantly increased the GAD65 mRNA expression at $6 \mathrm{~h}$, and the levels remained increased at 24 h. c, NPY and GAD65 mRNA expression in adjacent slices incubated with vehicle (control) or $10^{-9} \mathrm{M}$ insulin for $24 \mathrm{~h}$ is shown. The results are expressed as means $\pm \mathrm{SE}(n=10) .{ }^{*} p<0.05$ versus control. Scale bar, $20 \mu \mathrm{m}$.

\section{Effects of intracerebroventricular injection of insulin on GAD} mRNA expression

To see whether insulin could increase GAD65 expression in the arcuate nucleus in vivo, effects of intracerebroventricular injection of insulin on GAD65 mRNA were examined in rats fasted for $48 \mathrm{~h}$ without refeeding. The levels of GAD65 mRNA expression were significantly increased in rats injected with insulin compared with those in rats injected with vehicle $(191.9 \pm 22.9$ vs control rats, $100.0 \pm 13.1$ arbitrary units; $p<0.01)$.

\section{Discussion}

In this study, we first examined the regulation of NPY gene expression in hypothalamic organotypic cultures. Our in vitro data showed that (1) DEX increased NPY gene expression independently of action potentials, (2) insulin inhibited the NPY gene expression only in the presence of DEX, (3) the action of insulin on NPY gene expression was dependent on action potentials, and (4) GABAergic systems are likely to be involved in the inhibitory action of insulin on NPY gene expression. The possible role of GABAergic systems in mediating insulin action was further supported by the time course changes in GAD65 and NPY mRNA expression in the arcuate nucleus in the fasting-refeeding paradigm, as well as by the effects of central administration of insulin on GAD mRNA expression in vivo.

DEX is the synthetic glucocorticoid that binds to not only GR but also mineral corticoid receptors (MRs) in vitro (Reul et al., 2000). Because both GR and MR are expressed in the mediobasal hypothalamus in vivo (Reul et al., 2000), it is possible that the stimulatory effects of DEX on NPY mRNA expression in the present study might be mediated via not only GR but also MR, although a previous study demonstrated that NPY mRNA ex- 
pression in the arcuate nucleus was increased by the central administration of $\mathrm{GR}$, but not MR, agonists in vivo (White et al., 1994). The dose of DEX used in this study is similar to that measured in humans after injection of a clinically used amount of DEX (Osathanondh et al., 1977) and equivalent to physiological ranges of plasma glucocorticoid concentration. The doses of insulin used are within physiological ranges of the serum concentration, as shown in Figure $5 c$. Circulating insulin has been suggested to enter the brain via a transport system (Baura et al., 1993), and insulin concentrations in rat brain are shown to be $30-40 \%$ of plasma levels (Yalow and Eng, 1983). Thus, the doses of DEX and insulin used in this study are appropriate, and the findings in the hypothalamic organotypic cultures could well be physiologically relevant.

It has been shown that NPY gene promoter contains glucocorticoid-responsive elements and that dexamethasone increased the transcription of transfected as well as endogenous NPY gene expression in cell lines (Higuchi et al., 1988; Misaki et al., 1992). It has also been demonstrated that NPY immunoreactivities are increased by incubation with dexamethasone in rat fetal brain cells (Barnea et al., 1991) and dispersed hypothalamic neurons (Corder et al., 1988). In this study, we used the organotypic cultures from the rat mediobasal hypothalamus and showed that DEX increased NPY gene expression independently of action potentials in the arcuate nucleus, suggesting the direct action of glucocorticoids on NPY gene transcription and/or mRNA stability. However, it should be noted that explants from the mediobasal hypothalamus also include other hypothalamic nuclei, such as dorsomedial nucleus, ventromedial nucleus, and PVN, and that signals analyzed with films could contain the transcripts in these nuclei because they were reported to express NPY mRNA in vivo (Morris, 1989).

There is cumulative evidence that the inhibitory action of insulin on food intake is mediated via NPY neurons, although the detailed mechanisms have not been clear. In this study, we clearly demonstrated that insulin could act at the level of the hypothalamus to decrease NPY gene expression. Consistent with in vivo data that NPY expression was not increased by insulin deficiency in adrenalectomized rats (Ponsalle et al., 1992; Strack et al., 1995), our data also showed that the inhibitory action of insulin was only evident in the presence of DEX. Thus, it is suggested that glucocorticoids and insulin interact with each other at the level of the arcuate nucleus and regulate NPY gene expression, although our data do not exclude the other sites for possible interaction between glucocorticoids and insulin in vivo.

Our data showed that $\mathrm{GABA}_{\mathrm{B}}$ agonists inhibited DEX-
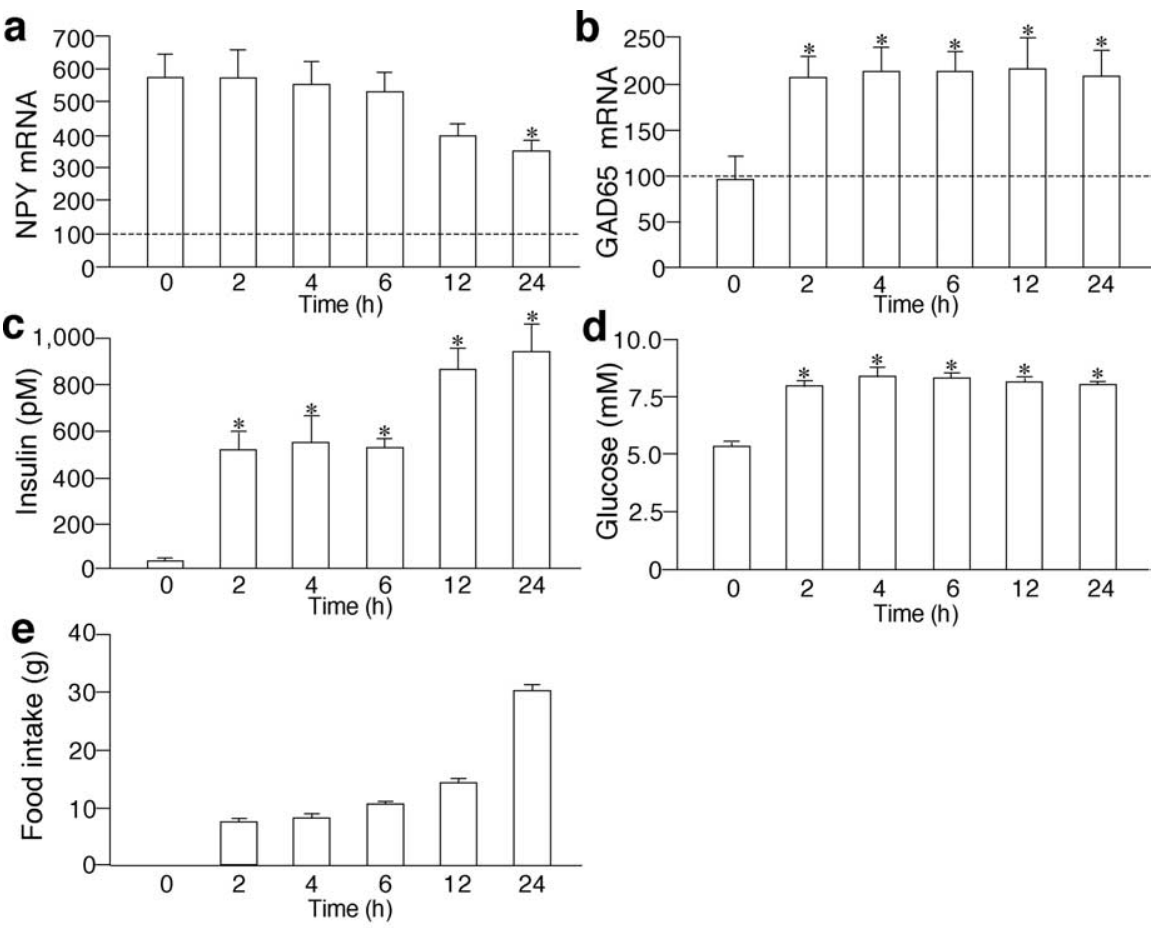

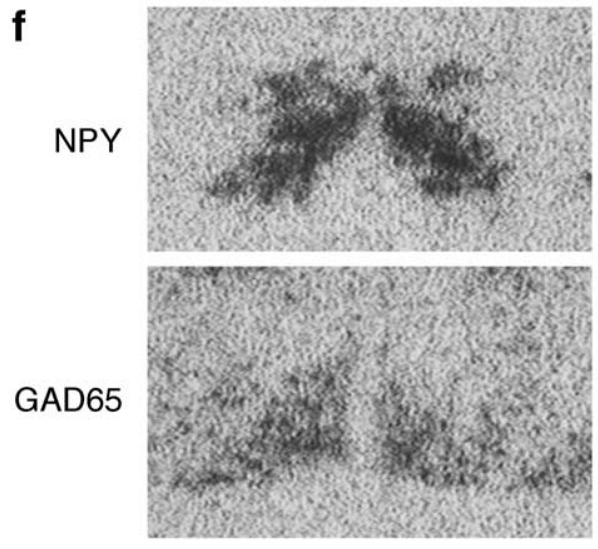

Fasted
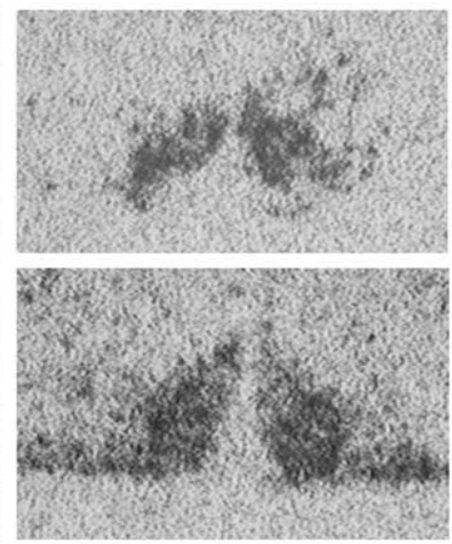

Refed
Figure 5. Changes in NPY $(\boldsymbol{a})$ and $\operatorname{GAD65}(\boldsymbol{b})$ mRNA in the arcuate nucleus, serum insulin levels $(\boldsymbol{c})$, blood glucose levels (d), and cumulative food intake $(\boldsymbol{e})$ in rats that had been deprived of food for $48 \mathrm{~h}$ and refed with normal rat chow for the duration indicated. The mean levels of NPY and GAD mRNA in rats that had access to food ad libitum were expressed as 100 and are shown as dashed lines. $\boldsymbol{f}$, NPY and GAD65 mRNA expression in adjacent slices before and $24 \mathrm{~h}$ after refeeding is shown. ${ }^{*} p<0.05$ versus values in rats fasted for $48 \mathrm{~h}$ (shown as time 0 in each panel).

stimulated NPY mRNA expression and that inhibitory action of insulin was completely abolished in the presence of $\mathrm{GABA}_{\mathrm{B}}$ antagonists. The $\mathrm{GABA}_{\mathrm{B}}$ receptors belong to a family of G-proteincoupled receptors and cAMP responsive element binding protein-2, a transcriptional factor acting either positively or negatively at cAMP responsive element (CRE) (Hai and Hartman, 2001), has been implicated in mediating the signaling (White et al., 2000; Vernon et al., 2001). Food deprivation was reported to induce CRE-mediated gene induction in the arcuate NPY neurons (Shimizu-Albergine et al., 2001), and, given the similarity between insulin and $\mathrm{GABA}_{\mathrm{B}}$ agonist action on NPY expression, it is possible that insulin increased GABA release, which in turn acted on $\mathrm{GABA}_{\mathrm{B}}$ receptors to suppress NPY gene expression through CRE-mediated mechanisms.

Experiments with $\mathrm{GABA}_{\mathrm{A}}$ antagonists suggest that NPY ex- 
pression is tonically suppressed through $\mathrm{GABA}_{\mathrm{A}}$ receptors. Previous study suggested that corticotropin-releasing hormone and vasopressin in the PVN are also tonically suppressed through $\mathrm{GABA}_{\mathrm{A}}$ receptors (Cole and Sawchenko, 2002), and it is demonstrated that such tonic inhibition was well maintained in the hypothalamic organotypic cultures over 2-3 weeks (Bali and Kovacs, 2003; Bartanusz et al., 2004) as in the present study, although it is still possible that synaptic connections were remodeled during culture. Because $\mathrm{GABA}_{\mathrm{A}}$ agonist did not decrease NPY gene expression significantly in the present study, increases in GABA release by itself would not affect NPY gene expression through $\mathrm{GABA}_{\mathrm{A}}$ receptors. However, insulin action was abolished in the presence of $\mathrm{GABA}_{\mathrm{A}}$ antagonist, suggesting that not only $\mathrm{GABA}_{\mathrm{B}}$ - but also $\mathrm{GABA}_{\mathrm{A}}$-mediated pathways were prerequisite for insulin action and that there might be an interaction between $\mathrm{GABA}_{\mathrm{A}^{-}}$and $\mathrm{GABA}_{\mathrm{B}}$-mediated signaling to suppress NPY gene expression. Previous studies demonstrated that insulin treatment increased the number of cell surface $\mathrm{GABA}_{\mathrm{A}}$ receptors in the hippocampus neurons (Wan et al., 1997) and that phosphorylation of $\mathrm{GABA}_{\mathrm{A}}$ receptors was found to modulate GABAgated currents (Swope et al., 1999). It should be noted, however, that incubation time with insulin in previous studies was much shorter than in this study, and more detailed exploration of the possible involvement of $\mathrm{GABA}_{\mathrm{A}}$ receptor-mediated signaling in the insulin action on NPY gene expression is warranted.

Approximately half of the neurons in the hypothalamus are GABAergic in vivo (Decavel and van den Pol, 1990), and GABA is shown to hyperpolarize most neurons in the arcuate nucleus (Loose et al., 1991; Wagner et al., 1998). In this study, we demonstrated that, as in vivo (Wisden et al., 1992; Schwartz et al., 1993; Kaupmann et al., 1997), GABA receptors are expressed in the hypothalamic slices and that most NPY neurons in the arcuate nucleus expressed GAD mRNA. We also demonstrated that insulin treatment significantly increased GAD65 mRNA expression in the arcuate nucleus. Because GAD65 is predominantly localized in axon terminals and involved in the synthesis and release of vesicular GABA (Soghomonian and Martin, 1998), our data suggest that insulin activated GABAergic systems and stimulated GABA release in the hypothalamic slices. Recently, Xu et al. (2005) reported that insulin activated phosphatidylinositol 3-kinase (PI3K) pathways in the neurons expressing agoutirelated protein in the arcuate nucleus that coexpress NPY and that the action was independent of action potentials (Xu et al., 2005). It is also reported that PI3K pathways mediated the inhibitory action of insulin on food intake (Niswender et al., 2003). Together, it is likely that GABAergic systems lie downstream of PI3K signalings and that the inhibitory action of insulin on NPY neurons was amplified through GABAergic systems. Previous studies suggested that GABA in NPY neurons could stimulate food intake by acting on PVN neurons after released with NPY (Kalra and Kalra, 2004) or by suppressing the activity of proopiomelanocortin neurons that also exist in the arcuate nucleus and play an inhibitory role in energy balance (Cowley et al., 2001). Our results do not necessarily conflict with these data but rather showed the diversity of GABA action.

To see whether the findings in the organotypic cultures are related to the regulation in vivo, we also examined the changes in NPY and GAD mRNA expression in the arcuate nucleus in a fasting-refeeding paradigm in which serum insulin levels were drastically changed. Our data showed that, as in the organotypic cultures, GAD65 mRNA was rapidly increased whereas NPY mRNA was gradually decreased after refeeding when serum insulin levels were elevated. Although it is possible that factors other than insulin regulate NPY as well as GAD mRNA expression in the arcuate nucleus, we also demonstrated in the present study that central administration of insulin significantly increased GAD65 mRNA expression in the arcuate nucleus in rats deprived of food without refeeding. These data as well as the similar time course changes in NPY and GAD65 mRNA between in vitro and in vivo experiments support the possible role of GABAergic systems mediating insulin action on NPY expression in the arcuate nucleus.

In conclusion, our data showed that insulin inhibited NPY gene expression stimulated by DEX in the arcuate nucleus in organotypic cultures. The effects of insulin were dependent on neural transmission, and GABAergic systems are likely to be involved in the insulin action on NPY neurons.

\section{References}

Arima H, House SB, Gainer H, Aguilera G (2002) Neuronal activity is required for the circadian rhythm of vasopressin gene transcription in the suprachiasmatic nucleus in vitro. Endocrinology 143:4165-4171.

Bäckberg M, Collin M, Ovesjö M-L, Meister B (2003) Chemical coding of $\mathrm{GABA}_{\mathrm{B}}$ receptor-immunoreactive neurones in hypothalamic regions regulating body weight. J Neuroendocrinol 15:1-14.

Bali B, Kovacs KJ (2003) GABAergic control of neuropeptide gene expression in parvocellular neurons of the hypothalamic paraventricular nucleus. Eur J Neurosci 18:1518-1526.

Barnea A, Cho G, Hajibeigi A, Aguila MC, Magni P (1991) Dexamethasoneinduced accumulation of neuropeptide- $\mathrm{Y}$ by aggregating fetal brain cells in culture: a process dependent on the developmental age of the aggregates. Endocrinology 129:931-938.

Bartanusz V, Muller D, Gaillard RC, Streit P, Vutskits L, Kiss JZ (2004) Local $\gamma$-aminobutyric acid and glutamate circuit control of hypophyseotrophic corticotropin-releasing factor neuron activity in the paraventricular nucleus of the hypothalamus. Eur J Neurosci 19:777-782.

Baura GD, Foster DM, Porte Jr D, Kahn SE, Bergman RN, Cobelli C, Schwartz MW (1993) Saturable transport of insulin from plasma into the central nervous system of dogs in vivo. A mechanism for regulated insulin delivery to the brain. J Clin Invest 92:1824-1830.

Benoit SC, Air EL, Coolen LM, Strauss R, Jackman A, Clegg DJ, Seeley RJ, Woods SC (2002) The catabolic action of insulin in the brain is mediated by melanocortins. J Neurosci 22:9048-9052.

Blasquez C, Jegou S, Feuilloley M, Rosier A, Vandesande F, Vaudry H (1994) Visualization of $\gamma$-aminobutyric acid $_{\mathrm{A}}$ receptors on proopiomelanocortin-producing neurons in the rat hypothalamus. Endocrinology 135:2759-2764.

Brüning JC, Gautam D, Burks DJ, Gillette J, Schubert M, Orban PC, Klein R, Krone W, Müller-Wieland D, Kahn CR (2000) Role of brain insulin receptor in control of body weight and reproduction. Science 289:2122-2125.

Clark JT, Kalra PS, Crowley WR, Kalra SP (1984) Neuropeptide Y and human pancreatic polypeptide stimulate feeding behavior in rats. Endocrinology 115:427-429.

Cole RL, Sawchenko PE (2002) Neurotransmitter regulation of cellular activation and neuropeptide gene expression in the paraventricular nucleus of the hypothalamus. J Neurosci 22:959-969.

Corder R, Pralong F, Turnill D, Saudan P, Muller AF, Gaillard RC (1988) Dexamethasone treatment increases neuropeptide $\mathrm{Y}$ levels in rat hypothalamic neurones. Life Sci 43:1879-1886.

Cowley MA, Smart JL, Rubinstein M, Cerdan MG, Diano S, Horvath TL, Cone RD, Low MJ (2001) Leptin activates anorexigenic POMC neurons through a neural network in the arcuate nucleus. Nature 411:480-484.

Dallman MF, la Fleur SE, Pecoraro NC, Gomez F, Houshyar H, Akana SF (2004) Minireview: glucocorticoids-food intake, abdominal obesity, and wealthy nations in 2004. Endocrinology 145:2633-2638.

Decavel C, van den Pol AN (1990) GABA: a dominant neurotransmitter in the hypothalamus. J Comp Neurol 302:1019-1037.

Decavel C, van den Pol AN (1992) Converging GABA- and glutamateimmunoreactive axons make synaptic contact with identified hypothalamic neurosecretory neurons. J Comp Neurol 316:104-116.

Hai T, Hartman MG (2001) The molecular biology and nomenclature of the activating transcription factor/cAMP responsive element binding family 
of transcription factors: activating transcription factor proteins and homeostasis. Gene 273:1-11.

Higuchi H, Yang HY, Sabol SL (1988) Rat neuropeptide Y precursor gene expression. mRNA structure, tissue distribution, and regulation by glucocorticoids, cyclic AMP, and phorbol ester. J Biol Chem 263:6288 -6295.

Hisano S, Kagotani Y, Tsuruo Y, Daikoku S, Chihara K, Whitnall MH (1988) Localization of glucocorticoid receptor in neuropeptide Y-containing neurons in the arcuate nucleus of the rat hypothalamus. Neurosci Lett 95:13-18.

Kalra SP, Kalra PS (2004) NPY and cohorts in regulating appetite, obesity and metabolic syndrome: beneficial effects of gene therapy. Neuropeptides 38:201-211.

Kaupmann K, Huggel K, Heid J, Flor PJ, Bischoff S, Mickel SJ, McMaster G, Angst C, Bittiger H, Froestl W, Bettler B (1997) Expression cloning of $\mathrm{GABA}_{\mathrm{B}}$ receptors uncovers similarity to metabotropic glutamate receptors. Nature 386:239-246.

Kuwahara S, Arima H, Banno R, Sato I, Kondo N, Oiso Y (2003) Regulation of vasopressin gene expression by cAMP and glucocorticoids in parvocellular neurons of the paraventricular nucleus in rat hypothalamic organotypic cultures. J Neurosci 23:10231-10237.

Loose MD, Ronnekleiv OK, Kelly MJ (1991) Neurons in the rat arcuate nucleus are hyperpolarized by $\mathrm{GABA}_{\mathrm{B}}$ and $\mu$-opioid receptor agonists: evidence for convergence at a ligand-gated potassium conductance. Neuroendocrinology 54:537-544.

Marks JL, Porte Jr D, Stahl WL, Baskin DG (1990) Localization of insulin receptor mRNA in rat brain by in situ hybridization. Endocrinology 127:3234-3236.

Misaki N, Higuchi H, Yamagata K, Miki N (1992) Identification of glucocorticoid responsive elements (GREs) at far upstream of rat NPY gene. Neurochem Int 21:185-189.

Morris BJ (1989) Neuronal localisation of neuropeptide Y gene expression in rat brain. J Comp Neurol 290:358-368.

Niswender KD, Morrison CD, Clegg DJ, Olson R, Baskin DG, Myers Jr MG, Seeley RJ, Schwartz MW (2003) Insulin activation of phosphatidylinositol 3-kinase in the hypothalamic arcuate nucleus: a key mediator of insulin-induced anorexia. Diabetes 52:227-231.

Obici S, Feng Z, Karkanias G, Baskin DG, Rossetti L (2002) Decreasing hypothalamic insulin receptors causes hyperphagia and insulin resistance in rats. Nat Neurosci 5:566-572.

Osathanondh R, Tulchinsky D, Kamali H, Fencl M, Taeusch Jr HW (1977) Dexamethasone levels in treated pregnant women and newborn infants. J Pediatr 90:617-620.

Paxinos G, Watson C (1998) The rat brain in stereotaxic coordinates. New York: Academic.

Ponsalle P, Srivastava LS, Uht RM, White JD (1992) Glucocorticoids are required for food deprivation-induced increases in hypothalamic neuropeptide Y expression. J Neuroendocrinol 4:585-591.

Reul JM, Gesing A, Droste S, Stec IS, Weber A, Bachmann C, Bilang-Bleuel A, Holsboer F, Linthost AC (2000) The brain mineralocorticoid receptor: greedy for ligand, mysterious in function. Eur J Pharmacol 405:235-249.

Schwartz MW, Figlewicz DP, Baskin DG, Woods SC, Porte Jr D (1992a) Insulin in the brain: a hormonal regulator of energy balance. Endocr Rev 13:387-414.

Schwartz MW, Sipols AJ, Marks JL, Sanacora G, White JD, Scheurink A, Kahn SE, Baskin DG, Woods SC, Figlewicz DP, Porte Jr D (1992b) Inhibition of hypothalamic neuropeptide $\mathrm{Y}$ gene expression by insulin. Endocrinology 130:3608-3616.
Schwartz MW, Sipols AJ, Grubin CE, Baskin DG (1993) Differential effect of fasting on hypothalamic expression of genes encoding neuropeptide $\mathrm{Y}$, galanin, and glutamic acid decarboxylase. Brain Res Bull 31:361-367.

Shimizu-Albergine M, Ippolito DL, Beavo JA (2001) Downregulation of fasting-induced cAMP response element-mediated gene induction by leptin in neuropeptide $\mathrm{Y}$ neurons of the arcuate nucleus. J Neurosci 21:1238-1246.

Sindelar DK, Mystkowski P, Marsh DJ, Palmiter RD, Schwartz MW (2002) Attenuation of diabetic hyperphagia in neuropeptide Y-deficient mice. Diabetes 51:778-783.

Sipols AJ, Baskin DG, Schwartz MW (1995) Effect of intracerebroventricular insulin infusion on diabetic hyperphagia and hypothalamic neuropeptide gene expression. Diabetes 44:147-151.

Soghomonian JJ, Martin DL (1998) Two isoforms of glutamate decarboxylase: why? Trends Pharmacol Sci 19:500-505.

Strack AM, Sebastian RJ, Schwartz MW, Dallman MF (1995) Glucocorticoids and insulin: reciprocal signals for energy balance. Am J Physiol 268:R142-R149.

Swope SL, Moss SJ, Raymond LA, Huganir RL (1999) Regulation of ligandgated ion channels by protein phosphorylation. Adv Second Messenger Phosphoprotein Res 33:49-78.

Vernon E, Meyer G, Pickard L, Dev K, Molnar E, Collingridge GL, Henley JM (2001) $\mathrm{GABA}_{\mathrm{B}}$ receptors couple directly to the transcription factor ATF4. Mol Cell Neurosci 17:637-645.

Wagner EJ, Bosch MA, Kelly MJ, Rønnekleiv K (1998) A powerful GABA receptor-mediated inhibition of GABAergic neurons in the arcuate nucleus. NeuroReport 9:4171-4177.

Wan Q, Xiong ZG, Man HY, Ackerley CA, Braunton J, Lu WY, Becker LE, MacDonald JF, Wang YT (1997) Recruitment of functional GABA $\mathrm{A}_{\mathrm{A}}$ receptors to postsynaptic domains by insulin. Nature 388:686-690.

White BD, Dean RG, Edwards GL, Martin RJ (1994) Type II corticosteroid receptor stimulation increases NPY gene expression in basomedial hypothalamus of rats. Am J Physiol 266:R1523-R1529.

White JH, McIllhinney RA, Wise A, Ciruela F, Chan WY, Emson PC, Billinton A, Marshall FH (2000) The $\mathrm{GABA}_{\mathrm{B}}$ receptor interacts directly with the related transcription factors CREB2 and $\mathrm{ATF}_{\mathrm{X}}$. Proc Natl Acad Sci USA 97:13967-13972.

Wilding JPH, Gilbey SG, Lambert PD, Ghatei MA, Bloom SR (1993) Increases in neuropeptide $\mathrm{Y}$ content and gene expression in the hypothalamus of rats treated with dexamethasone are prevented by insulin. Neuroendocrinology 57:581-587.

Wisden W, Laurie DJ, Monyer H, Seeburg PH (1992) The distribution of 13 $\mathrm{GABA}_{\mathrm{A}}$ receptor subunit mRNAs in the rat brain. I. Telencephalon, diencephalon, mesencephalon. J Neurosci 12:1040-1062.

Woods SC, Lotter EC, McKay LD, Porte Jr D (1979) Chronic intracerebroventricular infusion of insulin reduces food intake and body weight of baboons. Nature 282:503-505.

Xu AW, Kaelin CB, Takeda K, Akira S, Schwartz MW, Barsh GS (2005) PI3K integrates the action of insulin and leptin on hypothalamic neurons. J Clin Invest 115:951-958.

Yalow RS, Eng J (1983) Insulin in the central nervous system. Adv Metab Disord 10:341-354.

Zakrzewska KE, Cusin I, Stricker-Krongrad A, Boss O, Ricquier D, Jeanrenaud B, Rohner-Jeanrenaud F (1999) Induction of obesity and hyperleptinemia by central glucocorticoid infusion in the rat. Diabetes 48:365-370. 